\title{
On the origins of Italian anzi
}

\begin{abstract}
The diachronic investigation of discourse markers has proven challenging since its inception in the late Eighties. Their context dependency and frequent association with informal, colloquial usage have raised methodological, as well as theoretical, questions, as historical work has to rely on written texts, which record speech with varying degrees of accuracy, and provide no access to prosodic cues. Using Old to Present Day Italian databases, in particular the Opera del Vocabolario Italiano, the contribution details the evolution of discourse marker anzi 'on the contrary' from spatial and temporal uses to its present-day contrastive-corrective function, by focusing on the role of the comparative structure in the shift. The importance of different types of contexts and genres will be discussed, for instance, Old Italian volgarizzamenti, translations or adaptations (or both) of Latin prose originals into vernacular versions, where the rendering with anzi can be compared to the original item in the Latin source text.
\end{abstract}

Keywords: contrast; discourse markers, diachrony, Italian

\section{The evolution of anzi: Bazzanella (2003), Visconti (2015) and Musi (2016)}

Beside the mesmerizing cross-linguistic span of his research, a more subdued thread underlies, in my perception, Johan van der Auwera's vast and diverse production: the love for the more challenging "procedural" aspects of meaning, may these be realized in modality or in "little words", such as scalar additive operators, negative markers or connectives.

In this contribution, I will look at the origins of the Italian contrastive-corrective marker anzi 'on the contrary'. Starting from Bazzanella (2003), Visconti (2015) and Musi (2016), I will highlight some unresolved questions and suggest a possible new hypothesis. Data are from the large corpus Opera del Vocabolario

Jacqueline Visconti, University of Genova, Dipartimento di Italianistica, Romanistica, Antichistica, Arti e Spettacolo, Via Balbi 6, 16126, Genova, Italy, j.visconti@unige.it

כ Open Access. (C 2018 Jacqueline Visconti, published by De Gruyter. (c) BY-NC-ND This work is licensed under the Creative Commons Attribution-NonCommercial-NoDerivatives 4.0 License.

https://doi.org/10.1515/9783110607963-011 
Italiano (OVI), totalling 17,677,486 tokens of Tuscan texts from the thirteenth and fourteenth centuries and available online (e.g., Beltrami and Boccellari 2006).

Bazzanella (2003) considers both Latin ante and Italian anzi. Whereas ante has spatial, temporal and comparative functions, Old Italian anzi has both a temporal function, as in (1), and "contrastive-corrective" uses, as in (2). Only the latter survive in Present-Day Italian.

(1) pregò Domenedio e disse: Segniore Dio io ti prego, che tu mi facci due cose anzi ch'io muoia

'He prayed to the Lord and said: Lord I pray that you do two things to me anzi (before) I die.'

(OVI, Andrea da Grosseto, 1268 (tosc.) L. 3, cap. 2, 182.5)

(2) ché quelli che non teme Dio non è forte, anzi è pazzo

'For he who does not fear God is not strong, anzi (rather) he is mad.'

(OVI, Egidio Romano volg., 1288 (sen.), L. 1 pt., 2 cap. 13, 43.16)

As can be seen in (2), the contrastive-corrective use, which is available from the very first data, is typically realized in the form non $\mathrm{p}$, anzi q, where negation has scope over an entity already present in the discourse, typically someone else's point of view, which is refuted and replaced by q.

In some cases, the negation is absent, as in (3), where anzi is used to introduce a "better" formulation to replace the first one (p, anzi q). ${ }^{1}$

(3) non ti maravigliare se li uomini vanno a Dio, ché Dio venne alli uomini, anzi ne li uomini

'Do not wonder if men go to God, as God came to men, anzi (rather) in men.' (OVI, Fiori di filosafi, 1271-1275 (fior.), pag. 194.10)

The evolution of anzi is considered by Bazzanella (2003: 135) as a case of "modal drift" (deriva modale), which proceeds from spatial and temporal values to comparison and then contrast, according to the cline (which is not to be intended as strictly unidirectional, however) correlazione-opposizione-confronto-preferenzacontrasto-correzione 'correlation-opposition-comparison-preference-contrastcorrection'.

1 The proposed study is qualitative in nature. Indications on frequency are thus merely indicative. 
Building on this account, Visconti (2015) tries to identify the contexts that may have favored the shift from the temporal to the corrective value. According to her study, based on the OVI corpus, a crucial role in the shift from temporal to corrective is played by the construction anzi p che 'anzi p than q', which takes the form of a comparative structure. Consider (4) and (5):

(4) li buoni debbono anzi amare lo giudice che temere 'Good men must anzi (before/rather) love the judge than fear him.' (OVI, Andrea da Grosseto (ediz. Selmi), 1268 (tosc.) L. 2 cap. 40, 133.26)

(5) affaticati anzi per te che per altrui...

'Labour anzi (before/rather) for yourself than for the others.'

(OVI, Fiori di filosafi, 1271-1275 (fior.), 119.9)

Placing two states of affairs in a relation of temporal sequence, in a deontic or future reference context like (4) and (5), may indeed suggest an inference of precedence and priority, well-attested in studies on different languages. ${ }^{2}$ The subsequent step is an inference of rejection of the alternative in q, which paves the way for the shift from preference to correction. Let us look at hraðor, the comparative of hræpe 'quick, early', for instance. In Old English, it had both temporal precedence and preference values. As pointed out by Traugott and König (1991: 206), in contexts such as (6), we have an inference of refusal of one of the alternatives ('not to get married').

(6) His daughter, who had chosen the Lord, would rather die than get married. (Traugott and König 1991: 206)

Similarly, in (4), anzi amare che temere 'rather love than fear' would invite the inference 'not fear' and thus non temere, anzi amare 'not fear, rather love': the construction anzi p che q would thus prepare the ground for the shift from temporal sequence to correction, via precedence and priority.

In her study of the diachrony of anzi and invece 'instead', Musi (2016) separates adverbial/prepositional anzi from the conjunction anziché. Her argument is that, for the former, as seen, spatial-temporal and contrastive uses coexist from the beginning while, in the latter, the different stages in the development can still be identified (Musi 2016: 8). In particular, for anziché, cases like (7) can be found,

2 See, for instance, Traugott and König (1991) on English hraðor to rather, Cuenca (1992: 187) on Catalan ans, Rodriguez Somolinos (2002) on French ainz and Bazzanella (2003) on ante. 
in which the conjunction can be interpreted as either expressing anteriority between two states of affairs or as a marker of contrast.

(7) eh, maestro: i' ho veduto cosa che molto mi dispiace all'animo mio: ch'io vidi un vecchio di grandissimo tempo fare laide mattezze: onde, se la vecchiezza n'ha colpa io m'accordo di voler morire giovane anziché invecchiare e matteggiare

'Eh, master: I saw something which really displeased me: I saw an old man of really advanced age committing terrible follies: therefore, if old age is responsible for that, I have decided that I want to die young anziché (before/rather than) become old and go mad.'

(OVI, Novellino, 68, thirteenth century, Musi 2016: 9)

According to Musi (2016: 10), the conjunction's function of indicating preference is even clearer in examples where anzi is separated from the complementizer, as in (8).

(8) io le diedi per no' potere fare altro, $e$ Vollile anzi mandare che ritenerlle 'I have given them because I could not do anything else and I wanted anzi (rather) to send them than to keep them.'

(LIZ, Lett. Pist., 1320-1322, Musi 2016: 10)

In examples of this kind, it is argued, the conjunction anziché expands to contexts that are incompatible with a temporal meaning, such as (9).

(9) Tuttavolta il dolore somiglia anzi la quiete che l'inquietudine... 'Sometimes pain resembles anzi (rather) quietness than anxiety...' (LIZ, Tasso, De la Gelosia, 2. 137. 1585, Musi 2016: 11)

We notice, however, how the label of conjunction may be problematic in this example, given that anzi is followed by a nominal phrase. Interestingly, moreover, the use in (9) resembles the structure called "comparative" by Visconti (2015) for (4) and (5). For Musi (2016: 11) too, indeed, "the parallelism between two entities plays a fundamental role in the rise of the contrastive value".

As far as the evolution of the adverb anzi is concerned, Musi (2016) suggests that the contrastive value emerges from contexts following a negative clause, such as (2). 


\section{Unresolved questions}

The main issue, left open by Visconti (2015), concerns the role of the comparative structure in the development from the temporal to the corrective value of anzi and thus the relationship between the constructions: anzi p che q 'anzi $\mathrm{p}$ than q' and non q, anzi p 'not p, anzi q'.

The hypothesis of a crucial role of the comparative in the evolution from spatial-temporal to preference and correction finds support both in other languages, as noted above, and in the development of other conjunctions in Italian, such as ma 'but' or piuttosto 'rather' (e.g., Mauri and Giacalone Ramat 2015). In particular, the derivation of $m a$ (and its equivalents in Romance languages) from the Latin comparative adverb magis 'more' represents a significant precedent for anzi. The hypothesis, detailed in Marconi and Bertinetto (1984), concerns the shift from a construction of the kind p magis quam q ' $p$ more than q' to corrective (of the German sondern type) non q, ma(gis) p 'not q, but p', as in (10).

(10) id, Manli, non est turpe, magis miserum est

'This, Manlio, is not foul, magis (more) it is miserable.'

(Catullo, 68, 30, Ducrot and Vogt 1979)

As suggested by Marconi and Bertinetto (1984: 482), such a shift could originate in elliptical structures such as (11).

(11) non $q$, magis (quam $q$ ) $p>$ non $q$, ma (piuttosto che $q$ ) $p$

'not q, more (than q) p' > 'not q, but (rather than q) p'

An analogous elliptical structure could be assumed to have played a part in the evolution of anzi, as (12) shows.

(12) anzi $q$ che $p>$ non $p$, anzi (che $p$ ) $q>$ non $p$, anzi $q$

anzi amare che temere > non temere, anzi (che temere) amare > non temere, anzi amare

'before/rather love than fear' > 'not fear, rather (than fear) love' > 'not fear, rather love'

However, as argued by Marconi and Bertinetto (1984), explanations of this kind should not be accepted lightly, as the reconstruction of subjacent phenomena, when not made on the basis of compelling syntactic evidence, can easily border arbitrariness. Moreover, it is unlikely that speakers really opt for such convoluted 
ways to achieve their communicative purposes. This appeal to the speakers suggests an alternative hypothesis.

\section{A new hypothesis}

Let us start by refining the chronology of the phenomena, on the basis of the historical dictionary of Old Italian Tesoro della Lingua Italiana. Anzi is attested here already in 1211, with the value of a preposition expressing anteriority in time. It appears even earlier, already in the 12th century, as an adverb/conjunction with an adversative value (albeit with temporal connotations). The corrective value (i.e., the one without negation, as in p, anzi q) is attested at the end of the 13th century. A few examples of the spatial value persist into the 14th century.

As is well-known in diachronic research, due to the paucity and non-representativeness of the data, a definitive reconstruction of the phenomena is not always possible. Often, as for particles in physics, the only way is to look for their traces. One of the most interesting traces, which relates to the question of the complex relation between Latin and Vulgar of the time, is provided by volgarizzamenti, translations and adaptations of Latin and French texts into Vulgar. By looking at what anzi is a translation of, we can try to understand how it was perceived by the translator in those centuries.

Using the Dizionario dei Volgarizzamenti (Guadagnini and Vaccaro 2016; DiVo), ${ }^{3}$ we discover that, in the temporal uses, anzi translates Latin ante(quam), pridie (quam) and prius quam 'before'. In the comparative, anzi p che q renders nimis/potius/magis $\mathrm{p}$ quam q 'more $\mathrm{p}$ than $\mathrm{q}$ '. Yet, the most conspicuous Latin originals are sed 'but' in the adversative uses like (13) and immo 'rather' in the corrective ones like (14). ${ }^{4}$

3 Thanks to Elisa Guadagnini for her precious help with the database.

4 On immo, see Rosén (2003). 
(13) a. e se lli sovrani uomini e conosciuti cittadini Saturnini, Gracchi e Flacchi e molti altri maggiori non solamente non si contaminaro di sangue, anzi se n'adornaro d'onestade...

b. etenim si summi viri et clarissimi cives, Saturnini et Gracchorum et Flacci et superiorum complurium sanguine non modo se non contaminarunt, sed etiam honestarunt...

'If the highest and most famous citizens, Saturninus, and the Gracchi, and Flaccus and many that were not stained with blood, sed (but) also honored...'

(DiVo, Prima catilinaria volg. (red. A), a. 1294 (fior.), p. 5004.37: LAT)

(14) a. le cui bactaglie, ançi sotto le cui battaglie...

b. cuius bella immo sub cuius bellis...

'whose wars, immo (rather), under whose wars'

(DiVo, Bono Giamboni, Orosio volg. (ed. Matasci), a. 1292 (fior.), L. III, cap. 8, p. 30r.30: LAT)

Thus, if anzi is perceived as the equivalent of sed and immo (which moreover contains a scalar component) in the 13th century, its contrastive-corrective value appears to be fairly conventionalized already then. Assuming that this value is derived from a comparative structure, it is reasonable to conclude that the transition had already taken place in the documented period.

However, the high polysemy of anzi right from the start may induce us to consider a different hypothesis, according to which the contrast component would be in some way already present and inherent in anzi. ${ }^{5}$ By using anzi, whether to follow a negative clause or to introduce a reformulation, the medieval speaker would use it with the meaning of 'in front of, opposite', which is inherent in the spatial value of the particle. The spatial value in anzi is indeed of a relational kind - ' $p$ in front (of q)' - and contains a component of contrast, as already pointed out by Bazzanella (2003) and Musi (2016: 23).

As highlighted by Banfi and Arcodia (2009: 179) in a study of the derivation of coordinative markers in Indo-European languages, "the primary idea at the basis of the process of seriation is represented via morphs that highlight the 'antithesis', the 'contraposition' between the elements of a series”, in particular continuations of the Indo-European root * ${ }^{*}$ t- $i$. The outcomes of this basis indicating opposition/contrast, are locative forms, such as Sanskrit ánti 'opposed to, instead

5 I thank Lele Banfi for this important suggestion. 
of', Greek $\alpha v \tau i$ 'in place of, in the face of, close to' and, indeed, Latin ante/antea 'ahead of, before'.

The evolution of the meaning of anzi from spatial and temporal to contrast and correction would thus not have taken place in a linear way, through the mediation of the comparative structure, as envisaged by Visconti (2015). Rather, it would be the outcome of a series of parallel processes, by which the component of contrast, inherent in the spatial value, manifests itself in the different constructions in which anzi is realized: by following a negation, to suggest a point of view "in front" of a negated one or to introduce a better formulation "in front" of a previous, less adequate, one.

Both hypotheses look at the insidious ground of the relationship with the Latin tongue. Whereas the spatial, temporal and comparative uses of anzi continue those of Latin ante, the contrastive-corrective uses form an apparent innovation. From a first, yet authoritative survey, ${ }^{6}$ a corrective construction of the kind non turpe, ante miserum 'not foul, rather miserable' does not appear to exist in documented Latin. Such a construction was instead possible with magis, as in (10).

Yet, the existence in Medieval Latin of comparative structures such as (15) could, in the absence of further documents, endorse the original hypothesis of the development through the comparative.

(15) addere fecimus ut antea supercrescat quam deficiat

'Let us add so that there antea (rather) be too much than too little.'

(Adalhardi abb. Corbejens. statuta (a. 822), c. 6 ed. Levillain, LMA t. 13 (1900) p. 356)

Many unsolved questions, or, seen differently, many fascinating paths face us at this point - for instance, the role of Greek $\alpha v \tau i$, in which the component of contrast is strongly present or the Gallo-Romance influences, in particular the role of French ainz in the diffusion of anzi, as can be seen in the intermediate texts in DiVo, as in (16)

6 For which I thank Raffaella Tabacco. 
(16) a. se alcuna leggie difende che homo non frusti alcuno homo che ssia giudichato a morte, alcuna leggie dice che homo none ucida citadini dapnati, ansi ne i vé homo tucto giorno ischanpare

b. se aucune loi deffent que l'en ne frustast home jugé a mort, aucunes lois redient que l'en n'occie pas citien dampné, ainz l'en envoit l'en en exil a touzjors

c. an quia lex Porcia vetat? at aliae leges item condemnatis civibus non animam eripi, sed exilium permitti iubent. an quia gravius est verberari quam necari

'But according to other laws, the condemned should not be deprived of life, ansi (but rather) sent into exile.'

(DiVO, Orazioni di Cesare e Catone (red. alfa), 1285/99 (pis.), Oraz. di Cesare [Tes., III.35], pag. 122r.10: FR 51.22)

Moreover, an interesting hypothesis to be pursued further, given the dialogic nature of both contrast and correction, is the one of an origin of such values in rebuttal contexts, thus in orality.

\section{Conclusion}

The context dependency of procedural items like anzi and their frequent association with informal, colloquial usages make their diachronic investigation particularly challenging, as historical work has to rely on written texts, which record speech with varying degrees of accuracy and provide no access to prosodic cues. In this respect too, Johan's research has been paving the way across many languages and textual traditions.

\section{References}

Banfi, Emanuele \& Giorgio F. Arcodia. 2009. Conjunctive markers in (Mandarin) Chinese and Indo-European languages: An interlinguistic comparison. Studi e Saggi Linguistici 47. 169-186.

Bazzanella, Carla. 2003. Dal latino ante all'italiano anzi: La 'deriva modale'. In Alessandro Garcea (ed.), Colloquia absentium: Studi sulla comunicazione epistolare in Cicerone, 123140. Turin: Rosenberg.

Beltrami, Pietro G. \& Andrea Boccellari. 2006. Banche dati e dizionari on-line: Il Tesoro della Lingua Italiana delle Origini e la banca dati dell'italiano antico dell'Opera del Vocabolario 
Italiano. In Wolfgang Schweickard (ed.), Nuovi media e lessicografia storica: Atti del colloquio in occasione del settantesimo compleanno di Max Pfister, 3-14. Tübingen: Niemeyer. Cuenca, Maria Josep. 1992. Sobre l'evoluciò dels nexes conjunctus en català. Llengua y Literatura 5. 171-213.

Ducrot, Oswald \& Carlos Vogt. 1979. De magis à mais: Une hypothèse sémantique. Revue de Linguistique Romane 43 (171/172). 317-341.

Guadagnini, Elisa \& Giulio Vaccaro. 2016. Il passato è una lingua straniera: Il 'Dizionario dei Volgarizzamenti' tra filologia, linguistica e digital humanities. Bollettino dell'Opera del Vocabolario Italiano 21. 279-394.

Marconi, Diego \& Pier Marco Bertinetto. 1984. Ma in italiano, parte seconda: Proiezioni diacroniche. Lingua e Stile 19 (3). 475-509.

Mauri, Caterina \& Anna Giacalone Ramat. 2015. Piuttosto che: Dalla preferenza all'esemplificazione di alternative. Cuadernos de Filología Italiana 20. 49-72.

Musi, Elena. 2016. Semantic change from space-time to contrast: The case of Italian adversative connectives. Folia Linguistica 50 (1). 1-30.

Opera del Vocabolario Italiano. 1965. Florence: Consiglio nazionale delle Ricerche \& Accademia della Crusca.

Rodriguez Somolinos, Amalia. 2002. Ainz et mais en ancien français. Romania 120 (3/4). 505541.

Rosén, Hannah. 2003. Immo - its atypical use in Petronius. In József Herman \& Hannah Rosén (eds.), Petroniana: Gedenkschrift für Hubert Petersmann, 169-182. Heidelberg: Winter.

Tesoro della Lingua Italiana delle Origini. 1965. Florence: Consiglio nazionale delle Ricerche \& Accademia della Crusca.

Traugott, Elizabeth C. \& Ekkehard König. 1991. The semantics-pragmatics of grammaticalization revisited. In Elizabeth C. Traugott \& Bernd Heine (eds.), Approaches to grammaticalization, volume 1, 189-218. Amsterdam: John Benjamins.

Visconti, Jacqueline. 2015. La diacronia di anzi: Considerazioni teoriche, dati e prime ipotesi. Cuadernos de Filología Italiana 22. 105-116. 